\title{
Agronomic performances of three vetch species growing under different drought levels
}

\author{
Sywar Haffani ${ }^{*}$, Majid Mezni ${ }^{1}$, and Wided Chaïbi ${ }^{2}$
}

The current challenge of agriculture is to get the best yields while overcoming frequent water deficit conditions. The objective of this study was to compare performances of three vetch species (Vicia narbonensis L., V. sativa L., and V. villosa Roth) subjected to water stress. Plants were sown in pots under rainout shelter and submitted to four water regimes: control ( $100 \%$ field capacity [FC]), 80\%,60\%, and 40\% FC through 3 yr experiment. Results showed that V. narbonensis had the smallest declines in all the studied variables in response to water restriction but the highest water use efficiency (WUE) and stress tolerance index (STI) in both control and water-treated plants. This indicates the greater tolerance of this species to water constraint and its better water use. Vicia villosa was characterized by drastic declines in leaf area and DM yield (75\% and $64 \%$, respectively). It had also the smallest WUE and STI suggesting its low adaptation to water stress. Vicia sativa showed severe reductions in seed yield and yield components; accordingly, it was the most sensitive species in terms of seed yield. The three species implied avoidance strategies to cope with water stress. The different levels of drought tolerance explain the species ecological distribution in Tunisia.

Key words: Adaptation, growth, Vicia spp., water stress, water use efficiency, yield.

\section{INTRODUCTION}

Vetch species (Vicia narbonensis, V. sativa, and $V$. villosa) are common forage crops of the Fabacea family. Associated with oat, it is the most important fodder culture in the northern regions of Tunisia. Vetch and oat mixture occupies approximately 170000 ha. Like all legumes, vetch is a valuable crop as it enriches soil organic matter and $\mathrm{N}$ through symbiotic fixation. In Tunisia, vetch is normally grown in rainfed conditions of the semiarid and subhumid areas as cover crop and green manure. Despite the importance of vetches in the country, the area reserved to these crops has declined in recent years, probably because of the use of non adapted species.

Traditional protein sources for animal feed are becoming expensive in Tunisia. So, it is necessary to search for feeding alternatives based on local resources (Kökten et al., 2010; Selmi et al., 2010). That's why much interest is granted, actually, to vetch species as they are widespread in Tunisia. Moreover, the high nutritive value of their seeds suggests them as a substitute to soybean in animal rations (Larbi et al., 2010; Huseyin, 2014; Renna et

${ }^{1}$ Institut National de la Recherche Agronomique de Tunisie. Av. Hédi Karray, 2049 Ariana, Tunisia.

"Corresponding author (haffanisywar@gmail.com).

${ }^{2}$ Université Tunis El Manar, Faculté des Sciences de Tunis, 1060 Le belvédère, Tunisia.

Received: 25 November 2013.

Accepted: 28 June 2014.

doi:10.4067/S0718-58392014000300003 al., 2014). Furthermore, most farmers in Tunisia produce their own seeds. For these reasons great consideration is given to seed yield in this study.

Tunisia is under the impact of two contradictory climates: the Mediterranean in the North and the Saharian in the Center and the South; hence water stress is a major constraint in Tunisian agriculture. However, vetch species are not grown only in the north of the country. Vicia narbonensis $\mathrm{L}$. has a wide expansion ranging from the sub-humid to the arid region, $V$. sativa $\mathrm{L}$. occupies the semi-arid region, while V. villosa Roth lays in the northern regions of Tunisia. Accordingly, we have investigated in this study if their ecological distribution is due to different drought tolerance levels.

Among abiotic constraints, water deficit is the most important factor limiting crop production and causing relatively low and unstable yields worldwide and particularly in regions submitted to the Mediterranean climate. Drought occurs when the available water in the soil is reduced and atmospheric conditions cause continuous loss of water by transpiration or evaporation. Plants undergo morphological, physiological, and biochemical changes under water deficit conditions, resulting in decreases of leaf expansion, growth and hence DM and seed yield. Plant growth during water deficit was determined by estimating the relative growth rate (RGR), which represents gain of fresh weight per unit time. Growth is reduced because of photosynthesis decline which is due, in turn, to stomatal closure under severe and prolonged water constraint (Pettigrew, 2004). 
Plants, in Mediterranean climate, suffer from seasonal drought which affects forage yield and quality. Moreover, it has been demonstrated that water constraint causes a significant decrease of seed yield during several growth stages. Generally, under severe drought conditions during the reproductive phase, a lower number of inflorescences and a higher abortion rate are the main causes of seed yield reduction (Pettigrew, 2004). Accordingly, it is important that cultivated species have an adaptation to drought particularly through the optimization of water use. Water use efficiency (WUE) is the ability of the crop to produce biomass per unit of water transpired (Jaleel et al., 2008). Water use efficiency is assigned by photosynthetic capacity, stomatal behavior and leaf characteristics such size, structure and foliage orientation (Moreno et al., 2008). Harvest index (HI) is the ratio between seed yield and shoot DM. Both, HI and WUE are considered as important adaptive traits under water deficit conditions (Jaleel et al., 2008). Moreover, Fernandez (1993) defined a stress tolerance index (STI, calculated as the product of DM yields of control and stressed plants divided by average yield of all control plants), which can be used to identify the most productive genotypes under both stress and non-stress conditions.

Plants developed mechanisms to survive water limited conditions. These mechanisms could be classified as escape, avoidance, and tolerance. Drought escape represents the ability of a plant to complete its life cycle before the onset of severe soil water deficit (Moreno et al., 2008; Khan et al., 2010). Martinez et al. (2007) reported that this mechanism could be one of the most important features to minimize the impact of drought stress on crop production in common beans (Phaseolus vulgaris L.) Avoidance strategies are mechanisms that reduce water loss while maintaining water uptake, it includes stomatal closure, hydraulic conductance, changes in leaf area, leaf orientation, and anatomy and root growth patterns Osmotic adjustment and changes in tissue elasticity are classified as stress tolerance strategies (Iannucci et al., 2002).

Several studies about drought stress effect on growth and yield have been published, but very few have considered vetch species. To the best of our knowledge, no information on their tolerance to drought is available. A deeper understanding of species mechanisms to cope with water stress is necessary for breeders to identify the suitable plants to drought areas. Such data would be essential to promote the economic and environmental sustainability of crop-livestock systems in water limited regions. Therefore, this work aimed (i) to assess the vegetative growth and yield of three vetch species: Vicia narbonensis, V. sativa, and V. villosa under water stress conditions, (ii) to study plant strategies to withstand such constraint, and finally (iii) to determine if species drought tolerance explains their ecological distribution in Tunisia.

\section{MATERIALS AND METHODS}

\section{Growth conditions and water treatments}

The experiment was conducted during three seasons (20072008, 2008-2009, and 2009-2010) at the Tunisian National Institute of Agronomic Research, Ariana (36 $51^{\prime} 36^{\prime \prime}$ $\mathrm{N}, 10^{\circ} 11^{\prime} 36^{\prime \prime} \mathrm{E} ; 25 \mathrm{~m}$ a.s.l) Monthly temperatures and relative hygrometry of the experimental site are presented in Table 1. Four soil moisture treatments: 100\%, 80\%, $60 \%$, and $40 \%$ of field capacity (FC) were applied on three vetch species: Vicia narbonensis, $V$. sativa, and $V$. villosa. The control treatment was irrigated at $100 \%$ FC. The experimental design was a randomized complete factorial block with four replicates. Vetch species considered in this study are annual. So, sowing was carried out in midNovember for the $3 \mathrm{yr}$ of experimentation at 10 seeds per pot. This number is equivalent to the field theoretical density of 200 plants $\mathrm{m}^{-2}$. Vetch seeds were sown in pots $(25 \mathrm{~cm}$ diameter and $30 \mathrm{~cm}$ depth) maintained under rainout shelter. Pots were filled with $13 \mathrm{~kg}$ soil with physical and chemical characteristics presented in Table 2. Prior to potting, the soil was air dried and sieved. Water treatments were imposed by weighing pots daily and adding water as needed to keep the experimental required proportions. Field capacity was determined before sowing by watering pots to excess, covering them with plastic lids and allowing them to drain until reaching a constant weight. Thus, the weight difference between pot with humidity at saturation and that of dry pot corresponds to the amount of water at FC (4.19 L in our experiment). Water stress treatments were initiated only after the complete expansion of the third leaf (30 d after sowing). Weed control in pots was conducted manually.

Table 1. Monthly temperature and relative hygrometry through three growing seasons.

\begin{tabular}{lllrrrrrrr}
\hline & & Nov & Dec & Jan & Feb & Mar & Apr & May & June \\
\hline \multirow{2}{*}{ 2007-2008 } & Tmin, ${ }^{\circ} \mathrm{C}$ & 12.1 & 9.5 & 8.3 & 8.2 & 10.1 & 13.5 & 16.8 & 19.8 \\
& $\mathrm{Tmax},{ }^{\circ} \mathrm{C}$ & 19.8 & 16.6 & 17.3 & 17.6 & 19.4 & 23.7 & 26.3 & 30.7 \\
& $\mathrm{RH},{ }^{\circ}$ & 78.3 & 79.5 & 80.8 & 77.8 & 72.4 & 61.4 & 68.4 & 59.1 \\
& $\mathrm{Tmin},{ }^{\circ} \mathrm{C}$ & 12.9 & 9.0 & 8.9 & 7.9 & 9.7 & 12.2 & 16.2 & 19.6 \\
2008-2009 & $\mathrm{Tmax},{ }^{\circ} \mathrm{C}$ & 21.9 & 16.8 & 16.1 & 15.2 & 18.9 & 20.4 & 27.0 & 31.6 \\
& $\mathrm{RH},{ }^{\circ}$ & 68.5 & 74.6 & 79.9 & 73.4 & 72.2 & 78.0 & 64.9 & 53.9 \\
& $\mathrm{Tmin},{ }^{\circ} \mathrm{C}$ & 12.5 & 10.8 & 8.9 & 7.9 & 9.7 & 12.2 & 16.2 & 19.6 \\
2009-2010 & $\mathrm{Tmax},{ }^{\circ} \mathrm{C}$ & 22.6 & 19.6 & 16.1 & 15.2 & 18.9 & 20.4 & 27.0 & 31.6 \\
& $\mathrm{RH},{ }^{\circ}$ & 73.2 & 69.4 & 74.8 & 70.4 & 72.6 & 77.5 & 61.7 & 60.8 \\
\hline
\end{tabular}

Tmin: Minimal temperature, Tmax: maximal temperature, RH: relative humidity.

Table 2. Chemical and physical soil properties of the experimental location.

\begin{tabular}{lc}
\hline Measured parameters & Corresponding values \\
\hline Clay, \% & 30.0 \\
Fine silt, \% & 15.0 \\
Coarse silt, \% & 7.0 \\
Fine sand, \% & 26.0 \\
Coarse sand, \% & 21.0 \\
pH & 8.3 \\
Saturation, ${\mathrm{mL} 100 \mathrm{~g}^{-1}}_{\text {Conductivity, dS m }}^{-1}$ & 40.0 \\
Total limestone, \% & 5.2 \\
Organic matter, \% & 9.0 \\
Carbon, $\%$ & 0.8 \\
\hline
\end{tabular}




\section{Plant measurements}

Leaf area and shoot biomass are given on a seedling torn off thoroughly from each replicate. Leaf area was measured by weighing leaf heliographic copies and then relating this weight to that of known surface areas (Garcia et al., 2002). Leaves, stems, and roots were separated, oven dried at $80^{\circ} \mathrm{C}$ for $48 \mathrm{~h}$ and weighed. Relative growth rate (RGR) is expressed in mg plant ${ }^{-1} \mathrm{~d}^{-1}$ and calculated using the following formula (Radford, 1967):

$$
\mathrm{RGR}=\left(\ln \mathrm{DW}_{\mathrm{f}}-\ln \mathrm{DW} \mathrm{i}\right) /\left(\mathrm{t}_{\mathrm{f}}-\mathrm{t}_{\mathrm{i}}\right)
$$

where $D W_{i}$ is initial shoot dry weight, $D W_{f}$ is final shoot dry weight, $t$ is the time and the subscripts denote the final and initial sampling. RGR was calculated for three time intervals (37-71 DWT, 71-105 DWT, and 105-133 DWT) during the second year of study.

Dry matter yield $\left(\mathrm{g} \mathrm{cm}^{-1}\right)$ is calculated as the ratio of shoot DM to corresponding area. These measures were performed after $40 \mathrm{~d}$ of water treatment (DWT)) and the mean of 3 yr measurements is presented. Stress tolerance index (STI) was determined according to the following formula (Fernandez, 1993):

$$
\mathrm{STI}=\left[\left(\mathrm{Y}_{\mathrm{c}}\right) \times\left(\mathrm{Y}_{\mathrm{s}}\right) /\left(\overline{\mathrm{Y}}_{\mathrm{c}}\right)^{2}\right]
$$

where $Y_{c}$ and $Y_{s}$ are DM yields of control and stressed plants for each replicate, respectively, and $\bar{Y}_{c}$ is average DM yield of all control plants. Stress tolerance index is the mean of $3 \mathrm{yr}$ data.

Seed yield was measured by weighing seeds from the nine plants remaining in the pots. Yield components determined were inflorescences per plant, pods per plant, and seeds per pod. Harvest index (HI) was calculated as the ratio of seed yield to DM.

Water use efficiency (WUE, $\mathrm{g} \mathrm{L}^{-1}$ ) was determined four times (after 37, 71, 105, and 133 DWT) during 2008-2009 growing season. These harvests correspond to vegetative growth stage, flowering stage, pod formation stage, and pod filling stage, respectively. Water use efficiency was calculated for one plant from each replicate or pot (10 plants per pot) as the ratio of shoot DM to transpired water during the experiment (Wu et al., 2008). One pot from each replicate was kept with soil and plastic mulch, but without plants to measure evaporation. Water transpired was calculated by subtracting the water loss from pots containing plants (evapotranspiration) from those of empty pots (evaporative loss).

\section{Statistical analysis}

All data were subjected to ANOVA using proc mixed of SAS (version 8.0). Comparisons among water treatments and among species were performed using LSD option at 0.05 probability level. The significance of correlations between traits were determined using regression analysis at the $P=0.05$ threshold.

\section{RESULTS}

\section{Growth}

Water constraint severely affected leaf area (LA) and this effect was more pronounced with water deficit intensity. Vicia narbonensis was characterized by the highest LA under both control and stressed conditions (Figure 1). It showed also the least LA reductions under $80 \%$ FC and $40 \% \mathrm{FC}$ treatments (33\% and 60\%, respectively) in comparison to control. ANOVA showed highly significant differences $(P<0.001)$ between species, treatments and their interaction (Table 3). Relative growth rate (RGR) was reduced depending on water stress intensity in $V$. narbonensis and $V$. sativa; it decreased, also with water stress duration (Figure 2). Indeed, it was significantly higher during the 37-71 DWT interval compared with 71-105 DWT and 105-133 DWT intervals for all three species (Figure 2).

For $V$. narbonensis, RGR ranged from 18.4 to $16.4 \mathrm{mg}$ plant ${ }^{-1} \mathrm{~d}^{-1}$ during the vegetative growth stage and from 6.7 to $1.7 \mathrm{mg}_{\text {plant }}{ }^{-1} \mathrm{~d}^{-1}$ at pod formation and filling stage. The RGR reduction in this species is not significant at $40 \%$ FC treatment over control in the first time interval and became significant for 71-105 DWT and 105-133 DWT intervals (reached 32 and $75 \%$, respectively). As regards to $V$. sativa, RGR decreased severely with water stress duration and intensity, especially for the interval 105133 DWT, as it reached $0.6 \mathrm{mg}$ plant $^{-1} \mathrm{~d}^{-1}$ under severe water regime (40\% FC). Vicia villosa seems less affected

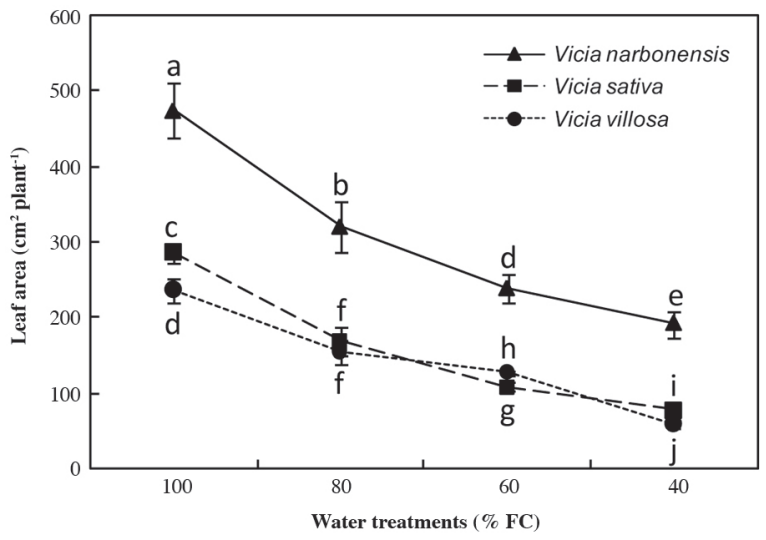

FC: Field capacity.

Figure 1. Water constraint effect on leaf area of three vetch species after $40 \mathrm{~d}$ of water treatment imposition. Bars represent standard error of four replicates mean.

Table 3. Standard errors of leaf area (LA) and dry matter yield of three vetch species under different water treatments.

\begin{tabular}{lcc}
\hline Source of variation & LA & DM Yield \\
\hline Species (1) & $3.33^{* * *}$ & $0.29^{* * * *}$ \\
Treatment (2) & $3.85^{* * *}$ & $0.34^{* * * *}$ \\
Year (3) & $3.33^{* * *}$ & $0.29^{* * * *}$ \\
$(1) \times(2)$ & $6.66^{* * *}$ & $0.58^{* * * *}$ \\
$(1) \times(2) \times(3)$ & $11.54^{* * *}$ & $1.01^{\text {**** }}$ \\
\hline
\end{tabular}

P $<0.05,{ }^{* *} \mathrm{P}<0.01$, and $^{* * *} \mathrm{P}<0.001$ 

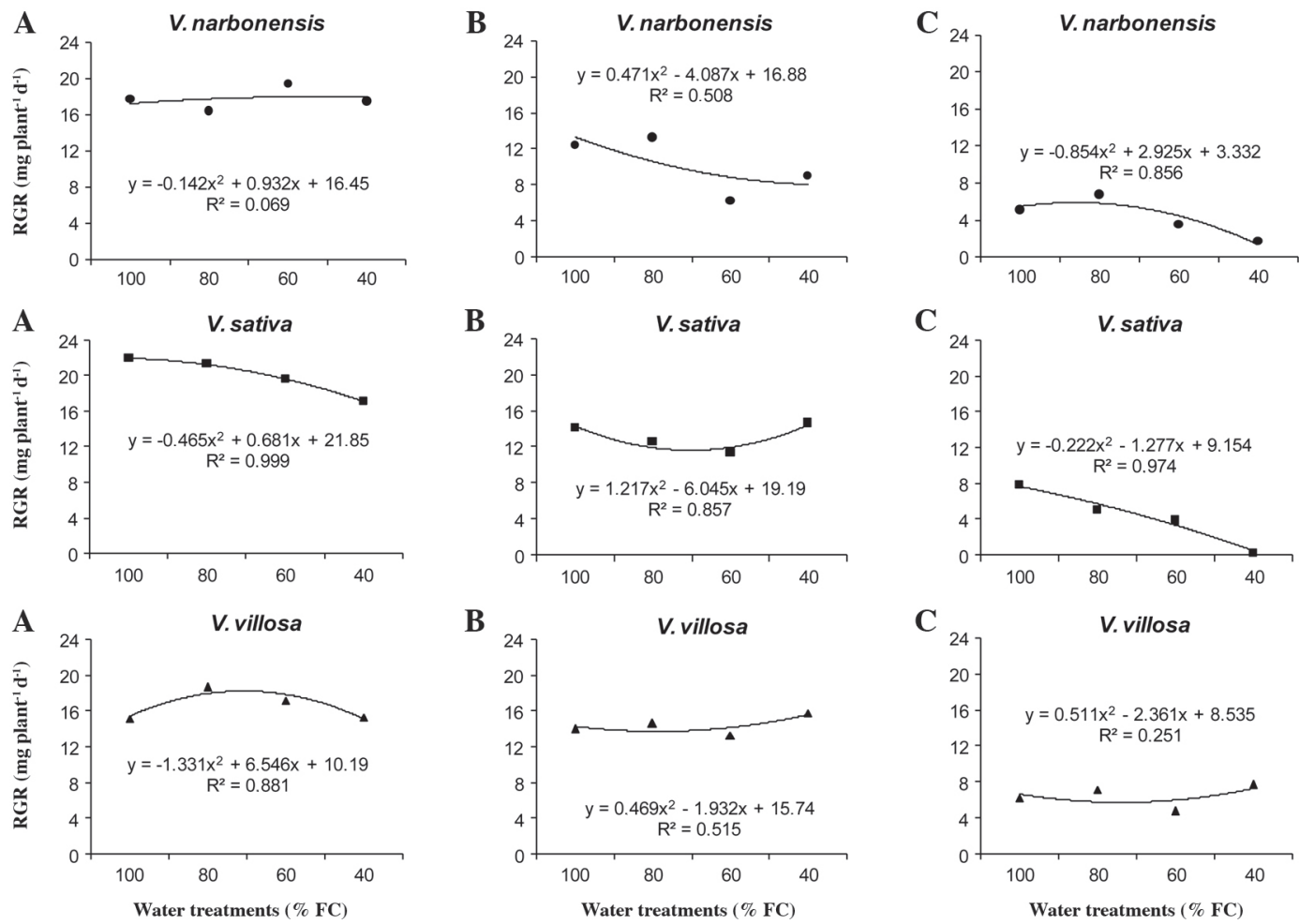

FC: Field capacity.

Figure 2. Water constraint effect on relative growth rate (RGR) of three vetch species.

by water stress intensity, but showed reductions in RGR depending on water stress duration. In this species, RGR variations were independent of water treatments as coefficients of determination $\left(R^{2}\right)$ passed from 0.89 at the beginning (37-71 DWT) to 0.19 at the end of the experiment (105-133 DWT). Besides, statistical analysis indicated highly significant differences between species and water treatments. Similarly, the species $\times$ treatment interaction was highly significant (Table 4).

\section{Dry matter yield and stress tolerance index (STI)}

Three years measures showed that water stress reduced DM yield in all three vetch species (Figure 3). Vicia narbonenis had significantly higher values compared to $V$. sativa and $V$. villosa across all watering treatments. However, the decline in DM yield, over control, was lower in $V$. narbonenis than the two other species under severe (40\% FC) water treatment (47\%). At this treatment, DM yield reduction reached $56 \%$ and $64 \%$ for $V$. sativa and $V$. villosa, respectively. ANOVA showed highly significant effects of Species, Water Treatments, Years, Species $\times$ Treatments, and Species $\times$ Treatments $\times$ Years interactions (Table 3).

Our results showed that STI decreased significantly with water constraint intensity (Table 5). The greatest values were observed in $V$. narbonensis under all water treatments while $V$. villosa had the lowest STI $(0.41,0.32$,
Table 4. Standard errors of relative growth rate (RGR) and water use efficiency (WUE) of three vetch species under different water treatments.

\begin{tabular}{|c|c|c|c|c|c|c|c|}
\hline \multirow[b]{2}{*}{$\begin{array}{l}\text { Source of } \\
\text { variation }\end{array}$} & \multicolumn{3}{|c|}{ RGR } & \multicolumn{4}{|c|}{ WUE } \\
\hline & $\begin{array}{l}37-71 \\
\text { DWT }\end{array}$ & $\begin{array}{l}\text { 71-105 } \\
\text { DWT }\end{array}$ & $\begin{array}{c}105-133 \\
\text { DWT }\end{array}$ & $\begin{array}{l}37 \\
\text { DWT }\end{array}$ & $\begin{array}{c}71 \\
\text { DWT }\end{array}$ & $\begin{array}{l}105 \\
\text { DWT }\end{array}$ & $\begin{array}{c}133 \\
\text { DWT }\end{array}$ \\
\hline Species (1) & $0.35^{* * *}$ & $0.26^{* * *}$ & $0.13^{* * *}$ & $0.037^{* * *}$ & $0.05^{* * *}$ & $0.07^{* * *}$ & $0.05^{* * *}$ \\
\hline Treatment (2) & $0.41^{* * *}$ & $0.30^{* * * * *}$ & $0.15^{* * * *}$ & $0.042^{* * * *}$ & $0.06^{* * * *}$ & $0.08^{* * s *}$ & $0.06^{* * * *}$ \\
\hline$(1) \times(2)$ & $0.70^{* * * *}$ & $0.52^{* * * *}$ & $0.25^{* * * *}$ & $0.073^{* * * *}$ & $0.10^{* * *}$ & $0.14^{* * *}$ & $0.10^{* * * *}$ \\
\hline
\end{tabular}

DWT: Days of water treatment: ${ }^{*} \mathrm{P}<0.05,{ }^{* *} \mathrm{P}<0.01$, and ${ }^{* * *} \mathrm{P}<0.001$.

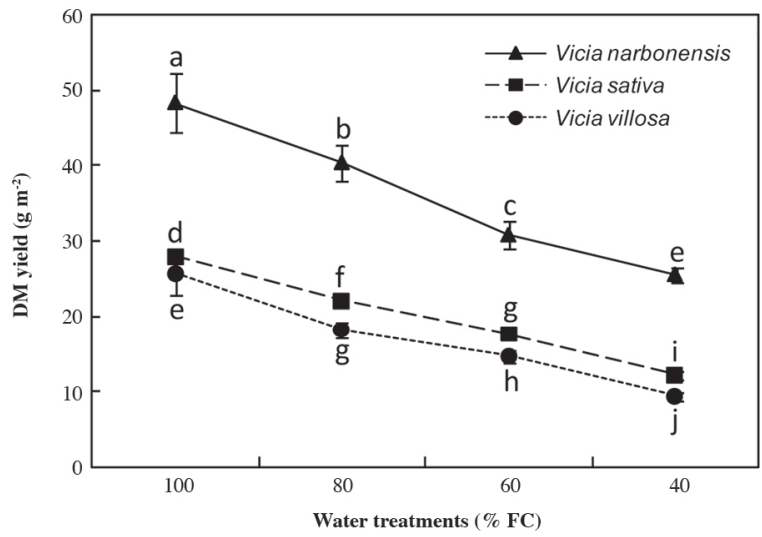

FC: Field capacity.

Figure 3. Water constraint effect on dry matter yield of three vetch species. Bars represent standard error of four replicates mean. 
Table 5. Mean values and standard errors for stress tolerance index of three vetch species under different water treatments.

\begin{tabular}{lccc}
\hline & Vicia narbonensis & Vicia sativa & Vicia villosa \\
\hline $80 \%$ FC & $1.48 \mathrm{a}$ & $0.57 \mathrm{~d}$ & $0.41 \mathrm{e}$ \\
$60 \%$ FC & $1.15 \mathrm{~b}$ & $0.45 \mathrm{e}$ & $0.32 \mathrm{f}$ \\
$40 \%$ FC & $0.90 \mathrm{c}$ & $0.31 \mathrm{f}$ & $0.20 \mathrm{~g}$ \\
\hline Species (1) & & $0.01^{* * * *}$ & \\
Treatment (2) & & $0.01^{* * *}$ & \\
Year (3) & $0.01 \mathrm{NS}$ & \\
$(1) \times(2)$ & $0.017^{* * * *}$ & \\
$(1) \times(2) \times(3)$ & & $0.029^{* * *}$ &
\end{tabular}

Means followed by the same letter are not significantly different at $\mathrm{P}<0.05$. NS: Non significant $(\mathrm{P}>0.05) ;{ }^{* * * *} \mathrm{P}<0.001 ; \mathrm{FC}$ : field capacity.

and 0.2). ANOVA showed highly significant differences between Species, Water Treatments and the interactions Species $\times$ Treatments, and Species $\times$ Treatments $\times$ Years. However, there were no significant differences between years (Table 5).

\section{Seed yield and seed yield components}

Seed yield and its components (number of inflorescences per plant, number of pods per plant, and number of seeds per pod) were severely affected by water constraint (Table 6). Vicia villosa had the greatest number of inflorescences per plant but the highest reduction compared to control under the most severe treatment during the $1^{\text {st }}$ and $3^{\text {rd }}$ years of experimentation (62\% and $69 \%$, respectively). Furthermore, $V$. narbonensis is the species that had the lowest decline in number of inflorescences per plant (59\%) considering $3 \mathrm{yr}$ mean. ANOVA indicated highly significant effects of species, treatment and interactions Species $\times$ Treatment and Species $\times$ Treatment $\times$ Year highlighting the phenotypic variability.

As regards to the number of pods per plant, it was highly affected by drought intensity (Table 6). Indeed, this parameter was significantly reduced by $55 \%, 55 \%$ and $42 \%$ FC under moderate drought and 68\%, 76\%, and $73 \%$ under severe one for $V$. narbonensis, V. sativa and $V$. villosa, respectively compared to control (mean of three years). The comparison of means showed highly significant differences between species and between water regimes. Similarly, the interactions Species $\times$ Treatment and Species $\times$ Treatment $\times$ Year were highly significant.

For the three species, the number of seeds per pod was slightly less affected by water deficit than the other yield components. Vicia sativa was characterized by the greatest number of seeds per pod under both normal and water limited conditions. Three years mean reductions were $25 \%, 20 \%$, and $31 \%$ under moderate water constraint $(60 \% \mathrm{FC})$ and $44 \%, 37 \%$, and $54 \%$ under severe one (40\% FC) for $V$. narbonensis, V. sativa, and $V$. villosa, respectively. Highly significant differences were observed between species and treatments for the number of seeds per pod. Nevertheless, the interactions between Species $\times$ Treatment and Species $\times$ Treatment $\times$ Year were not significant $(P>0.05)$ (Table 6).

Concomitant with the decrease in yield components, seed yield decreased under water shortage (Table 6). Moreover, V.narbonensis had the greatest yield in control and other water regimes. During the $3 \mathrm{yr}$ experimentation, the most severe yield reduction was observed for $V$. sativa $(75 \%)$ under the $40 \%$ FC. In addition, statistical analysis showed highly significant differences between species, treatments and significant interactions Species $\times$ Treatment and Species $\times$ Treatment $\times$ Year.

Furthermore, water constraint lead to a slight decline of HI (Table 6). Vicia narbonensis had the greatest values the first two growing seasons ( 0.45 and 0.54 , respectively) under control conditions and 40\% FC (0.38 and 0.36,

Table 6. Mean values and standard errors for yield and yield components of three vetch species under different water treatments through three years experiment.

\begin{tabular}{|c|c|c|c|c|c|c|c|c|c|c|c|c|c|c|c|}
\hline \multirow{2}{*}{$\frac{\text { Parameters }}{\text { Year } 1}$} & \multicolumn{3}{|c|}{$\begin{array}{c}\text { Number of } \\
\text { inflorescences per plant }\end{array}$} & \multicolumn{3}{|c|}{$\begin{array}{l}\text { Number of pods } \\
\text { per plant }\end{array}$} & \multicolumn{3}{|c|}{$\begin{array}{l}\text { Number of seeds } \\
\text { per pod }\end{array}$} & \multicolumn{3}{|c|}{$\begin{array}{l}\text { Seed yield } \\
\left(\mathrm{g}_{\text {plant }}{ }^{-1}\right)\end{array}$} & \multicolumn{3}{|c|}{ Harvest index } \\
\hline & $\mathrm{N}$ & $\mathrm{S}$ & $\mathrm{V}$ & $\mathrm{N}$ & $\mathrm{S}$ & V & $\mathrm{N}$ & $\mathrm{S}$ & $\mathrm{V}$ & $\mathrm{N}$ & S & $\mathrm{V}$ & $\mathrm{N}$ & $\mathrm{S}$ & V \\
\hline $100 \% \mathrm{FC}$ & $15 \mathrm{fg}$ & $30 \mathrm{~d}$ & $71 \mathrm{a}$ & $8 g$ & $25 d$ & $55 \mathrm{a}$ & $4 a$ & $5 a$ & $3 b$ & $6.40 \mathrm{a}$ & $4.69 \mathrm{~b}$ & $3.19 \mathrm{c}$ & $0.45 \mathrm{a}$ & $0.38 \mathrm{bcd}$ & $0.41 \mathrm{ab}$ \\
\hline $80 \% \mathrm{FC}$ & $12 \mathrm{gh}$ & $24 \mathrm{e}$ & $58 b$ & $6 \mathrm{gh}$ & $16 \mathrm{e}$ & $43 b$ & $3 b$ & $4 a$ & $3 b$ & $4.35 b$ & $2.67 \mathrm{~d}$ & $2.64 d$ & $0.38 \mathrm{bcd}$ & $0.29 \mathrm{e}$ & $0.40 \mathrm{abc}$ \\
\hline $60 \% \mathrm{FC}$ & $9 \mathrm{hi}$ & $18 \mathrm{f}$ & $46 c$ & $3 \mathrm{hi}$ & $12 \mathrm{f}$ & $33 c$ & $3 b$ & $4 a$ & $2 \mathrm{c}$ & $3.23 \mathrm{c}$ & $2.07 \mathrm{e}$ & $1.87 \mathrm{e}$ & $0.40 \mathrm{abcd}$ & $0.34 \mathrm{de}$ & $0.39 \mathrm{bcd}$ \\
\hline $40 \% \mathrm{FC}$ & $6 \mathrm{i}$ & $12 \mathrm{gh}$ & $27 \mathrm{de}$ & $2 \mathrm{i}$ & $7 \mathrm{gh}$ & $15 \mathrm{e}$ & $2 c$ & $3 b$ & $2 \mathrm{c}$ & $2.17 \mathrm{e}$ & $1.33 \mathrm{f}$ & $0.98 \mathrm{f}$ & $0.38 \mathrm{bcd}$ & $0.35 \mathrm{~cd}$ & $0.36 \mathrm{bcd}$ \\
\hline \multicolumn{16}{|l|}{ Year 2} \\
\hline $100 \% \mathrm{FC}$ & $13 \mathrm{f}$ & $28 \mathrm{~b}$ & $46 a$ & $7 f$ & $24 b$ & $34 a$ & $3 \mathrm{~cd}$ & $5 \mathrm{a}$ & $3 \mathrm{~cd}$ & $7.15 \mathrm{a}$ & $3.43 \mathrm{c}$ & $2.46 \mathrm{~d}$ & $0.54 \mathrm{a}$ & $0.33 \mathrm{de}$ & $0.34 \mathrm{de}$ \\
\hline $80 \%$ FC & $10 \mathrm{~g}$ & $22 d$ & $30 b$ & $4 \mathrm{~g}$ & $18 \mathrm{c}$ & $24 b$ & $2 \mathrm{ef}$ & $4 \mathrm{~b}$ & $3 \mathrm{de}$ & $4.90 \mathrm{~b}$ & $2.26 \mathrm{de}$ & $1.84 \mathrm{f}$ & $0.46 \mathrm{~b}$ & $0.26 \mathrm{fg}$ & $0.29 \mathrm{ef}$ \\
\hline $60 \% \mathrm{FC}$ & $8 \mathrm{~g}$ & $16 \mathrm{e}$ & $26 c$ & $3 \mathrm{gh}$ & $11 \mathrm{e}$ & $16 \mathrm{~d}$ & $2 \mathrm{fg}$ & $3 c$ & $2 \mathrm{~g}$ & $3.35 \mathrm{c}$ & $1.42 \mathrm{~g}$ & $1.19 \mathrm{~g}$ & $0.40 \mathrm{c}$ & $0.26 f g$ & $0.29 \mathrm{ef}$ \\
\hline $40 \% \mathrm{FC}$ & $5 \mathrm{~h}$ & $10 \mathrm{~g}$ & $21 d$ & $2 \mathrm{~h}$ & $4 \mathrm{gh}$ & $8 f$ & $2 \mathrm{~g}$ & $3 \mathrm{~cd}$ & $1 \mathrm{~h}$ & $2.03 \mathrm{ef}$ & $0.69 \mathrm{~h}$ & $0.56 \mathrm{~h}$ & $0.36 \mathrm{~cd}$ & $0.21 \mathrm{~h}$ & $0.22 \mathrm{gh}$ \\
\hline \multicolumn{16}{|l|}{ Year 3} \\
\hline $100 \% \mathrm{FC}$ & $15 \mathrm{ef}$ & $31 d$ & $98 \mathrm{a}$ & $8 \mathrm{fgh}$ & $26 \mathrm{~d}$ & $76 a$ & $4 b c$ & $5 a$ & $4 \mathrm{bcd}$ & $5.55 \mathrm{a}$ & $5.60 \mathrm{a}$ & $4.22 \mathrm{~b}$ & $0.36 \mathrm{~cd}$ & $0.41 b c$ & $0.51 \mathrm{a}$ \\
\hline $80 \%$ FC & $13 \mathrm{ef}$ & $26 \mathrm{~d}$ & $87 b$ & $6 \mathrm{ghi}$ & $14 \mathrm{e}$ & $61 b$ & 3 cde & $4 \mathrm{ab}$ & $3 \mathrm{ef}$ & $3.44 \mathrm{c}$ & $2.84 \mathrm{~d}$ & $3.35 \mathrm{c}$ & $0.28 \mathrm{e}$ & $0.28 \mathrm{e}$ & $0.49 \mathrm{a}$ \\
\hline $60 \% \mathrm{FC}$ & $10 \mathrm{fg}$ & $17 \mathrm{e}$ & $66 c$ & $4 \mathrm{hi}$ & $11 \mathrm{ef}$ & $50 \mathrm{c}$ & 3 def & $4 \mathrm{ab}$ & $3 \mathrm{ef}$ & $2.52 \mathrm{de}$ & $2.18 \mathrm{ef}$ & $2.28 \mathrm{ef}$ & $0.32 \mathrm{de}$ & $0.32 \mathrm{de}$ & $0.41 \mathrm{bc}$ \\
\hline $40 \% \mathrm{FC}$ & $6 \mathrm{~g}$ & $11 \mathrm{fg}$ & $31 d$ & $3 i$ & $8 f g$ & $23 d$ & $2 \mathrm{ef}$ & $3 \mathrm{cde}$ & $2 \mathrm{f}$ & $1.94 \mathrm{f}$ & $1.47 \mathrm{~g}$ & $1.30 \mathrm{~g}$ & $0.34 \mathrm{de}$ & $0.34 \mathrm{de}$ & $0.46 \mathrm{ab}$ \\
\hline Species (1) & \multicolumn{3}{|c|}{$0.44^{* * * * *}$} & \multicolumn{3}{|c|}{$0.32^{* * * * *}$} & \multicolumn{3}{|c|}{$0.07^{* * * *}$} & \multicolumn{3}{|c|}{$0.04^{* * * *}$} & \multicolumn{3}{|c|}{$0.006^{* * *}$} \\
\hline Treatment (2) & \multicolumn{3}{|c|}{$0.51^{* * * * *}$} & \multicolumn{3}{|c|}{$0.37^{* * * *}$} & \multicolumn{3}{|c|}{$0.08^{* * * *}$} & \multicolumn{3}{|c|}{$0.05^{* * * *}$} & \multicolumn{3}{|c|}{$0.007^{* * * *}$} \\
\hline Year (3) & \multicolumn{3}{|c|}{$0.44^{* * * *}$} & \multicolumn{3}{|c|}{$0.32^{* * * *}$} & \multicolumn{3}{|c|}{$0.07^{* * * *}$} & \multicolumn{3}{|c|}{$0.04^{* * * *}$} & \multicolumn{3}{|c|}{$0.006^{* * *}$} \\
\hline$(1) \times(2)$ & \multicolumn{3}{|c|}{$0.88^{* * * *}$} & \multicolumn{3}{|c|}{$0.64^{* * * *}$} & \multicolumn{3}{|c|}{$0.14 \mathrm{NS}$} & \multicolumn{3}{|c|}{$0.08^{* * * *}$} & \multicolumn{3}{|c|}{$0.012 \mathrm{NS}$} \\
\hline$(1) \times(2) \times(3)$ & \multicolumn{3}{|c|}{$1.53^{* * * *}$} & \multicolumn{3}{|c|}{$1.12^{* * * *}$} & \multicolumn{3}{|c|}{$0.24 \mathrm{NS}$} & & $0.15^{* * * * *}$ & & & $0.021^{* * * *}$ & \\
\hline
\end{tabular}

$\mathrm{N}$ : Vicia narbonensis, S: Vicia sativa, V: Vicia villosa, FC: field capacity.

Means followed by the same letter within a section are not significantly different at $P<0.05$.

NS: Non significant, ${ }^{* * *} P<0.001$ 
respectively). In the third year of experimentation, the greatest HI was observed in V. villosa in both control and severe drought (0.51 and 0.46 , respectively). Besides, the effects species, treatments, Species $\times$ Treatments and Species $\times$ Treatments $\times$ Year interactions were highly significant.

\section{Water use efficiency}

Water use efficiency increased with water treatment duration in both control and water limited conditions. However, it decreased with the intensity of water constraint (Figure 4). Under control conditions, WUE ranged from 3.28 to $5.67 \mathrm{~g} \mathrm{~L}^{-1}$ for $V$. narbonensis, 1.84 to $5.05 \mathrm{~g} \mathrm{~L}^{-1}$ for V. sativa, and 2.33 to $3.74 \mathrm{~g} \mathrm{~L}^{-1}$ for $V$. villosa
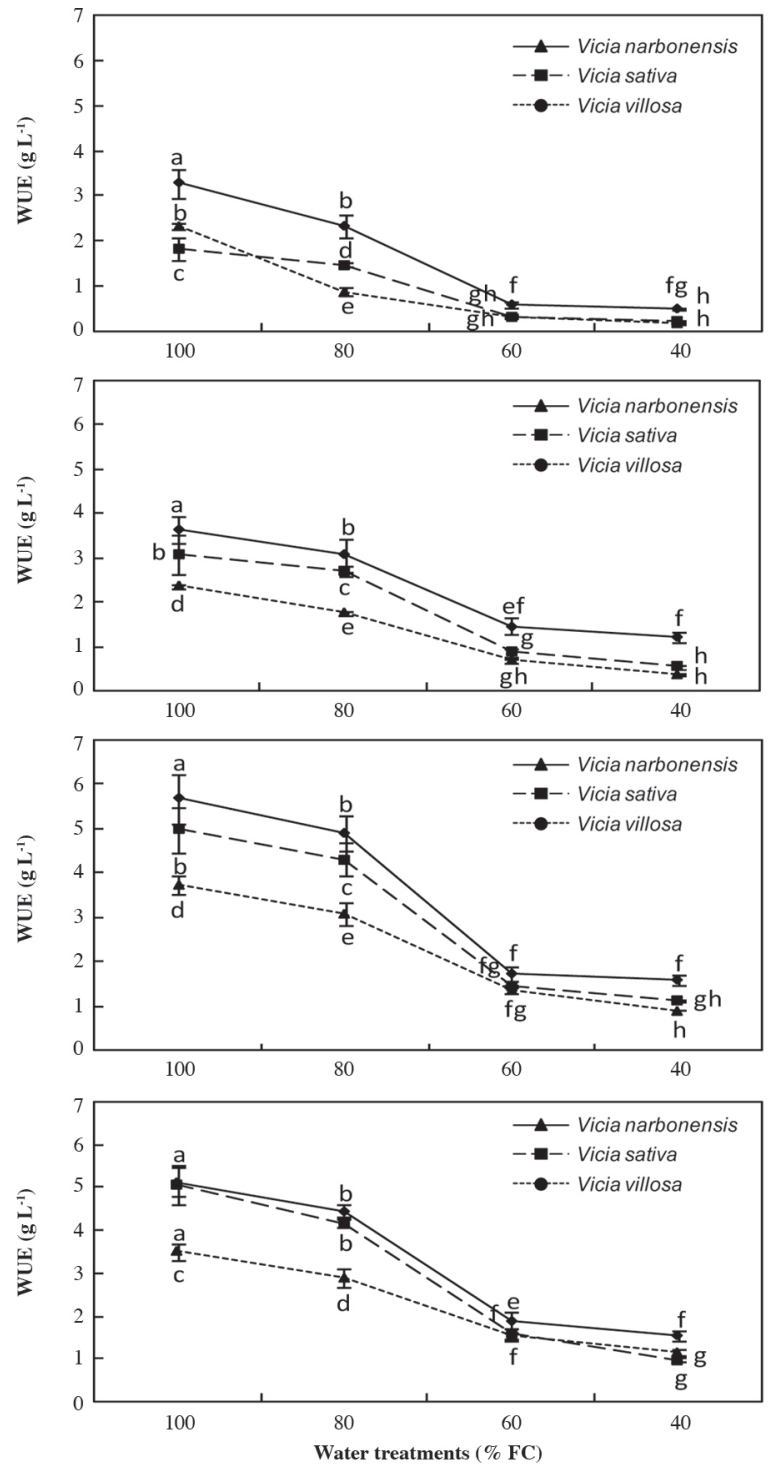

DWT: Days of water treatment; FC: field capacity.

Figure 4. Water constraint effect on water use efficiency (WUE) at four measurement dates: A: 37 DWT, B: 71 DWT, C: 105 DWT, and D: 133 DWT. Bars represent standard error of four replicates mean. after 37 and 133 d water treatment (DWT), respectively. After 37 DWT, WUE was 81\%, 82\%, and 86\% lower for $V$. narbonensis, $V$. sativa, and $V$. villosa than that for control under moderate drought (60\% FC), while the reductions were $84 \%, 87 \%$, and $91 \%$ for the three species respectively under severe water constraint (40\% FC). Moreover, after 133 DWT, these reductions tend to decrease. Indeed, WUE was 63\%, 69\%, and 57\% lower than control under $60 \% \mathrm{FC}$ and $70 \%, 81 \%$, and $67 \%$ under $40 \%$ FC for V.narbonensis, V. sativa, and V. villosa, respectively. Table 4 indicates significant differences between species, treatments, and a significant interaction Species $\times$ Treatment concerning the four measurement dates.

\section{DISCUSSION}

Water deficit led to a decrease in growth parameters (LA and RGR). Confronted to such constraint, plants develop several adaptive mechanisms to stand drought and to insure survival and reproduction (Vurayai et al., 2011). Severe water stress (40\% FC) reduced LA by $60 \%, 73 \%$, and $75 \%$ in V. narbonensis, V. sativa, and V. villosa, respectively. Leaves are, thereby, the most sensitive organs of the plant. Indeed, the plant's first response under water constraint is to reduce its LA in order to minimize water loss (Villagra and Cavagnaro, 2006). Furthermore, LA decrease for the three vetch species is caused by a diminished leaf number under water deficit in addition to the reduction in the limb surface. This decline in leaf number may be due to either limitation of new leaves formation or old leaves abscission. Accordingly, these adaptive responses at the leaf level affect plant productivity through photosynthesis reduction which leads to decrease biomass and seed yield (Vurayai et al., 2011). Reducing LA is a drought avoidance strategy for the plants by reducing transpiration and avoiding low water potential which allows more water uptake (Villagra and Cavagnaro, 2006).

Relative growth rate (RGR) is an efficient physiological index for comparing effects of agronomic characters (Stolf et al., 2009); RGR was high at the beginning of the experiment for the three vetch species and decreased significantly from 71-105 DWT. Indeed, in early stages, plants are in vegetative growth phase and from 91 DWT, flowering starts in V. narbonensis. So, the reproductive stage begins and plants assign DM to the reproductive organs. Rosales et al. (2012) reported that effective mobilization of available assimilates, during the reproductive stage, seems to be a priority in water stress conditions. It should be noted that $V$. sativa showed the greatest reduction in RGR at $40 \%$ FC. This is the result of a high decrease in LA per plant $(73 \%)$ as was observed by Bell (2005) on alfalfa. Similarly, Stolf et al. (2009) showed that RGR reduction in soybean is due to leaf abscission and low development of new leaves. 
Dry matter yield declined progressively in response to reduction in soil water availability. It was reduced by $47 \%, 56 \%$, and $64 \%$ compared with the control for $V$. narbonensis, $V$. sativa, and $V$. villosa, respectively, under severe water deficit. Such reductions under water stress have been reported for many annual or perennial forages legumes (Busso et al., 1998; Acuña et al., 2010; Erice et al., 2010). LA reductions induced by water restrictions negatively affects photosynthesis and thus biomass production. Saeed and Nadi (1997) explained forage yield decrease in alfalfa under water stress conditions by the reduction in stem density, stem length and leaf area. Besides, Aranjuelo et al. (2001) reported that alfalfa forage yield decreased due to the decline in photosynthesis which resulted from leaf area decrease and reduction of RuBisCo enzyme activity.

Vicia narbonensis was characterized by the greatest DM yield for all water treatments. This can be explained, on one hand, by its larger RGR as was indicated by Muhammad et al. (2010) on 13 forage legumes. These authors stated that higher growth rates might have resulted higher light interception and hence higher DM. It can be explained, on the other hand, by its larger LA. According to Annicchiarico (2007), higher leaf area leads to higher forage and biomass production. Figure 5 showed high correlations $\left(\mathrm{R}^{2}=0.913\right)$ between LA and DM yield. But no relationship was observed between DM yield and RGR (Figure 5). Mefti et al. (2008) reported that DM yield performance was independent from RGR.

Stress tolerance index was higher in $V$. narbonensis compared to the other species concerning all the water regimes which indicates the superiority of the species in terms of drought tolerance. There is a highly significant correlation between DM yield and STI $\left(\mathrm{R}^{2}=0.943\right)$ (Figure 5). Accordingly, this index may be effective in identifying high productive cultivars under water deficit conditions. Water stress reduced seed yield and yield components in all stressed treatments as compared to control. These reductions confirm previous findings on annual clovers
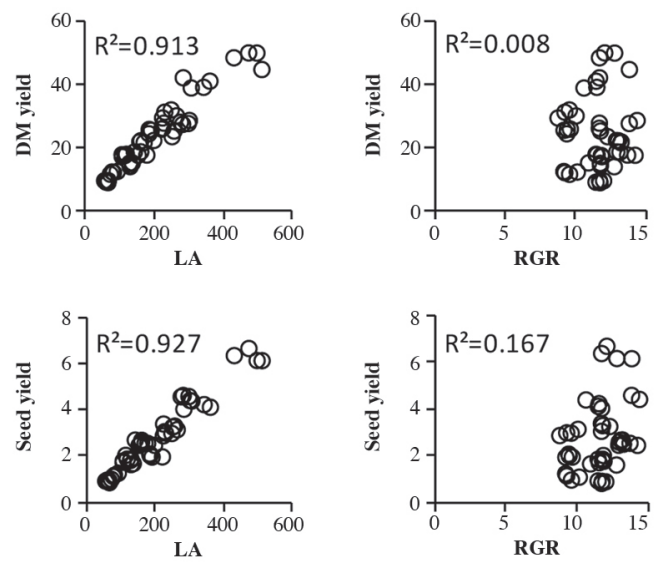

(Iannucci et al., 2002) and faba bean (Ghassemi-Golezani et al., 2009). According to Gorai et al. (2010), lowering production constitutes an adaptive mechanism which reduces plant's water needs in Medicago sativa L. and Astragalus gombiformis (Pom.), respectively. Besides, seed number decrease is considered as an avoidance strategy to cope with water stress (Tardieu et al., 2006). Khan et al. (2010) reported that drought affects seed yield of faba bean by reducing total biomass production. The number of pods per plant was the most sensitive yield component to water constraint in our study. Chebouti and Abdelguerfi (2004) and Martinez et al. (2007) reported the same results on three species of Medics and common bean, respectively. The reduced number of pods per plant is probably due to flowers abortions. Thus, the low yields recorded under the severe water regime are partly explained by the reduced number of inflorescences and pods per plant as it was suggested by Martin et al. (2003) in white clover. Similarly, Nielsen (1996) reported that the reduction in seed yield of canola is due to a lower number of inflorescences per plant, pods per inflorescence and smaller seeds.

Vicia narbonensis was less affected by water constraint compared with $V$. sativa and $V$. villosa. It showed smaller reductions of the number of inflorescences and pods per plant under severe drought compared to control during $3 \mathrm{yr}$ experiment. Accordingly, seed yield, which is the resultant of these components, underwent the least decrease $(67.6 \%)$. Adjustment of these variables demonstrates the ability of this species to develop characters of adaptation to an imposed water shortage. Leaf water status parameters (relative water content, water potential, and stomatal conductance) demonstrated the superiority of $V$. narbonensis in comparison with the two other species (Haffani et al., 2014). Besides, it was characterized by a shorter growth cycle than $V$. sativa and $V$. villosa (data no shown), which allowed it to escape terminal drought. For $V$. sativa, the number of pods per plant and yield were severely affected under the $40 \% \mathrm{FC}$ water treatment
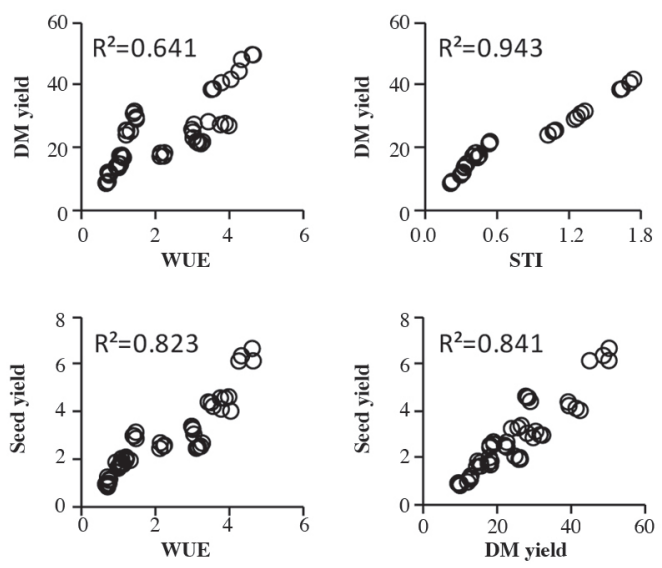

Figure 5. Regression analysis of dry matter yield $\left(\mathrm{g} \mathrm{m}^{-2}\right)$, leaf area $\left(\mathrm{LA}, \mathrm{cm}^{2}\right.$ plant $\left.^{-1}\right)$, relative growth rate $\left(\mathrm{RGR}, \mathrm{mg} \mathrm{plant}^{-1} \mathrm{~d}^{-1}\right)$, water use efficiency $\left(\mathrm{WUE}, \mathrm{g} \mathrm{L}^{-1}\right)$, stress tolerance index (STI) and seed yield $\left(\mathrm{g} \mathrm{plant}^{-1}\right)$. 
(75.6\% and $75.3 \%$, respectively) mostly explained by flower and pod abscission. Despite the high number of inflorescences, flowers and pods, $V$. villos $a$ had low yields because of the small seed size. Moreover, water potential reductions under water stress were more pronounced than relative water content decreases indicating that the three vetch species involved avoidance strategies to retain water in their leaf tissues (Haffani et al., 2014).

Seed yield was strongly related to leaf area $\left(R^{2}=0.927\right)$ and to DM yield $\left(\mathrm{R}^{2}=0.841\right)$ (Figure 5). Mwanamwenge et al. (1999) and Ghassemi-Golezani et al. (2009) reported a correlation between DM production and grain yield in faba bean. According to Xue et al. (2006), photosynthesis reduction and accelerated leaf senescence under water constraint during the grain filling period are considered as major causes of grain yield decline of wheat. The grain filling stage largely determines the final yield that is regulated by source/sink relationships. Clavel et al. (2005) indicated that water deficit during this phase affects particularly certain physiological and biochemical processes conditioning the seed quality. The performance of many varieties has been improved by shortening the cycle length in almost all annual crops in order to escape drought (Clavel et al., 2005).

Our results showed that $\mathrm{HI}$ decreased under severe drought stress (40\% FC) while there was no significant differences between the other water treatments concerning the three vetch species. Reductions in HI due to drought have also been reported by Ramirez-Builes (2007) in several common bean genotypes. According to Barrios et al. (2005) the number of seeds per pod and weight of individual seeds reduced the HI and final bean yield. Furthermore, HI reductions are interpreted by either a limitation of the source or the sink or a limitation of assimilates transfer from the source to the sink, according to the stages (Debaeke et al., 1996). The $3 \mathrm{yr}$ mean HI of $V$. narbonensis showed the highest values for the control and the $40 \%$ FC water regime, indicating the improved resistance of this species to drought.

Moreover, an efficient use of limited water resources and a better growth are desirable traits for crops in drought environments (Jaleel et al., 2008). Many previous studies have observed that WUE declines under water stress conditions and sustained that the species employed a water-use strategy ( $\mathrm{Hu}$ et al., 2006; Gorai et al., 2010). Blum (2005) considered lower WUE as an avoidance strategy. However some others have found the inverse case, i.e. WUE is improved under water limited conditions (Jaleel et al., 2008; Molero et al., 2008; Moreno et al., 2008). Indeed, increases of WUE under water constraint are due to a proportionally greater reduction in transpiration than photosynthesis because of stomatal closure (Moreno et al., 2008). In this study, WUE declined with drought intensity for the three vetch species. Several authors explained differently this behavior. First, according to $\mathrm{Wu}$ et al. (2008), WUE decrease may be attributed to a low biomass production under severe water deficit conditions. Secondly, Gorai et al. (2010) sustained that WUE reduction under drought is due to an optimal water use by plants. Thirdly, Moreno et al. (2008) claimed that this behavior is caused by the predominance of non stomatal limitation to photosynthesis and by the fact that stomata are less sensitive to water deficit. Finally, Molero et al. (2008) reported that WUE reductions are induced by the worse regulation of stomata opening when submitted to water constraint.

In addition, our data showed that WUE increased with water deficit duration for both control and treated plants. In fact, plants developed mechanisms of adaption to water constraint through the optimization of water use. Qiu et al. (2008) reported that the greatest WUE variation occurred among growing stages rather than among irrigation treatments. Besides, WUE was positively associated with DM yield $\left(\mathrm{R}^{2}=0.641\right)$ as was reported by Saeed and El-Nadi (1997) and Mefti et al. (2008). A significant relationship was observed between WUE and seed production $\left(\mathrm{R}^{2}=0.823\right)$ as was indicated in several studies such as Hu et al. (2006) and Neal et al. (2011).

\section{CONCLUSIONS}

Water constraint led to decreases in growth, DM yield, water use efficiency (WUE), seed yield, and yield components in the three studied vetch species. However, it turned out that Vicia narbonensis was the most tolerant species to drought stress. The superiority of this species was because of its larger leaf area (LA) and higher relative growth rate. Moreover, it showed the smallest reductions of growth and yield and maintained the highest values of WUE and stress tolerance index in both control and water limited conditions. Vicia sativa and V. villosa had similar behavior with a small advantage of the latter. In fact, $V$. villosa had the most important reductions in DM Yield while $V$. sativa was the most affected species by water stress concerning seed production and water use efficiency (WUE). This study showed the importance of $V$.narbonensis for fodder and seed production in the areas where water is a limiting factor.

Previous findings including physiological variables indicated that the three vetch species involved avoidance strategies (reduction of LA, seed number, and WUE) to withstand water deficit. Nevertheless, $V$. narbonensis used both escape and avoidance mechanisms. Further studies must be done at the cellular and molecular level to determine if these species imply tolerance strategies when submitted to water constraint.

Moreover, the ecological distribution of these species is justified by our results. The large distribution of $V$. narbonensis is explained by its higher adaptation to water constraint. Vicia sativa and V. villosa areas are restricted to the northern and central Tunisia, which is in agreement with their lower adaptation to drought conditions. 


\section{ACKNOWLEDGEMENTS}

This research was supported by Institut National de Recherche Agronomique de Tunisie. We thank Dr Brahim Marzouk from "Centre de Biotechnologie de Borj Cedria" for reviewing the article.

\section{LITERATURE CITED}

Acuña, H., L. Inostroza, M.P. Sánchez, and G. Tapia. 2010. Droughttolerant naturalized populations of Lotus tenuis for constrained environments. Acta Agriculturae Scandinavica Section B Soil and Plant Science 60:174-181. doi:10.1080/09064710902800224.

Annicchiarico, P. 2007. Lucerne shoot and root traits associated with adaptation to favourable or drought-stress environments and to contrasting soil types. Field Crops Research 102:51-59. doi:10.1016/j.fcr.2007.01.005.

Aranjuelo, M.I., J.J. Irigoyen, and M.S. Diaz. 2001. Effect of increased temperature and drought associated to climate change on change on productivity of nodulated alfalfa. p. 153-156. In Delgado I., and J. Lloveras (eds.) Quality in lucerne and medics for animal production. Options Méditerranéennes: Série A. Séminaires Méditerranéens 45. XIV Eucarpia Medicago SPP. Group Meeting, Zaragoza and Lleida, Spain.

Barrios, A.N., G. Hoogenboom, and D.S. Nesmith. 2005. Drought stress and the distribution of vegetative and reproductive traits of a bean cultivar. Scientia Agricola 62:18-22. doi:10.1590/S010390162005000100004.

Bell, L.W. 2005. Relative growth rate, resource allocation and root morphology in the perennial legumes, Medicago sativa, Dorycnium rectum and D. hirsutum grown under controlled conditions. Plant and Soil 270:199-211. doi:10.1007/s11104-0041495-6.

Blum, A. 2005. Drought resistance, water-use efficiency, and yield potential - are they compatible, dissonant, or mutually exclusive? Australian Journal of Agricultural Research 56:1159-1168. doi:10.1071/AR05069.

Busso, C.A., O.A. Fernandez, and D.E. Fresnillo Fedorenko. 1998. Dry weight production and partitioning in Medicago minima and Erodium cicutarium under water stress. Annals of Botany 82:217227. doi:10.1006/anbo.1998.0667.

Chebouti, A., and A. Abdelguerfi. 2004. Effect of water stress on growth and forage yield of three species of medics. p. 319321. In Ferchichi, A. (ed.) Rangeland and pasture rehabilitation in Mediterranean areas. Cahiers Options Méditerranéennes 62. 489 p. Centre International de Hautes Etudes Agronomiques Méditerranéennes (CIHEAM), Paris, France.

Clavel, D., P. Baradat, J.L. Khalfaoui, N.K. Drame, N.D. Diop, O. Diouf, et al. 2005. Adaptation à la sécheresse et création variétale: le cas de l'arachide en zone sahélienne. Oléagineux Corps Gras Lipides 14:293-308. doi:10.1684/oc1.2007.0141.

Debaeke, P., J. Puech, M.L. Casals, et P. Petibon. 1996. Élaboration du rendement du blé d'hiver en conditions de déficit hydrique. I. Étude en lysimètres. Agronomie 16:3-23. doi:10.1051/ agro.19960101.

Erice, G., S. Louahlia, J.J. Irigoyen, M. Sanchez-Diaz, and J.C. Avice. 2010. Biomass partitioning, morphology and water status of four alfalfa genotypes submitted to progressive drought and subsequent recovery. Journal of Plant Physiology 167:114-120. doi:10.1016/j.jplph.2009.07.016.

Fernandez, G.C.J. 1993. Effective selection criteria for assessing plant stress tolerance. p. 257-270. In Adaptation of Food Crops to Temperature and Water Stress: Proceedings of an International Symposium, Taiwan, China. 13-18 August 1992. Publication nr 93-410. 531 p. Asian Vegetable Research and Development Center, Taipei, China.
Garcia, M.G., C.A. Busso, P. Polci, N.L. García Girou, and V. Echenique. 2002. Water relations and leaf growth rate of three Agropyron genotypes under water stress. Biocell 26:309-317.

Ghassemi-Golezani, K., S. Ghanehpoor, and M.N. Dabbagh. 2009. Effects of water limitation on growth and grain filling of faba bean cultivars. Journal of Food, Agriculture and Environment 7:442447. doi:1459-0255/Jfoodagrienviron1459-0263.

Gorai, M., A. Hachef, and M. Neffati. 2010. Differential responses in growth and water relationship of Medicago sativa (L.) cv. Gabès and Astragalus gombiformis (Pom.) under water-limited conditions. Emirates Journal of Food and Agriculture 22:1-12. doi:2079-0538/emiratejfoodagr2079-052X.

Haffani, S., M. Majid, I. Slama, M. Ksontini, and W. Chaibi. 2014. Plant growth, water relations and proline content of three vetch species under water-limited conditions. Grass and Forage Science 69:323-333. doi:10.1111/gfs.12034.

Hu, Y.C., H.B. Shao, L.Y. Chuc, and W. Gang. 2006. Relationship between water use efficiency (WUE) and production of different wheat genotypes at soil water deficit. Colloids and Surfaces B 53:271-277. doi:10.1016/J.colsurfb.2006.10.002.

Huseyin, K.F. 2014. A comparison of six vetches (Vicia spp.) for developmental rate, herbage yield and seed yield in semiarid central Turkey. Grass and Forage Science 69:303-314. doi:10.1111/gfs.12021.

Iannucci, A., M. Russo, L. Arena, N. Di Fonzo, and P. Martiniello. 2002. Water deficit effects on osmotic adjustment and solute accumulation in leaves of annual clovers. European Journal of Agronomy 16:111-122. doi:10.1016/S1161-0301(01)00121-6.

Jaleel, C.A., P. Manivannan, G.M.A. Lakshmanan, M. Gomathinayagam, and R. Panneerselvam. 2008. Alterations in morphological parameters and photosynthetic pigment responses of Catharanthus roseus under soil water deficits. Colloids and Surfaces B 61:298-303. doi:10.1016/j.colsurfb.2007.09.008.

Khan, H.R., J.G. Paull, K.H.M. Siddique, and F.L. Stoddard. 2010. Faba bean breeding for drought-affected environments: A physiological and agronomic perspective. Field Crops Research 115:279-286. doi:10.1016/j.fcr.2009.09.003.

Kökten, K., A. Koçak, E. Bağci, M. Akçura, and S. Çelik. 2010. Tannin, protein contents and fatty acid compositions of the seeds of several Vicia L. species from Turkey. Grasas Aceites 61:404408. doi:10.3989/gya.021310.

Larbi, A., S. Hassan, G. Kattash, A.M. Abd El-Moneim, B. Jammal, H. Nabila, et al. 2010. Annual feed legume yield and quality in dryland environments in north-west Syria: 2. Grain and straw yield and straw quality. Animal Feed Science and Technology 160:90-97. doi:10.1016/j.anifeedsci.2010.07.004.

Martin, R.J., R.N. Gillespie, S. Maley, and M. Robson. 2003. Effect of timing and intensity of drought on the seed yield of white clover (Trifolium repens L.) p. 172-174. In Solutions for a Better Environment. Proceedings of the $11^{\text {th }}$ Australian Agronomy Conference, Gree long, Victoria. 2-6 February 2003. Australian Society of Agronomy, Gree long, Australia.

Martinez, J.P., H. Silva, J.F. Ledent, and M. Pinto. 2007. Effect of drought stress on the osmotic adjustment, cell wall elasticity and cell volume of six cultivars of common beans (Phaseolus vulgaris L.) European Journal of Agronomy 26:30-38. doi:10.1016/j. eja.2006.08.003.

Mefti, M., H. Bouzerzour, A. Abdelguerfi, and H. Nouar. 2008. Morphological and growth characteristics of perennial grass cultivars grown under semi-arid conditions of the Algerian high plateaus. Journal of Agronomy 7:138-147. doi:10.3923/ ja.2008.138.147.

Molero, G., I. Aranjuelo, and S. Nogués. 2008. Study of seasonal variation on WUE of eight varieties of lucerne plants exposed to drought. p. 341-344. In Porqueddu C., and M.M. Tavares de Sousa (eds.) Sustainable Mediterranean grasslands and their multi-functions. Options Méditerranéennes: Série A. Séminaires Méditerranéens 79. CIHEAM-IAMZ/FAO/ENMP/SPPF CIHEAM/FAO, Zaragoza, Spain. 
Moreno, M., J. Gulías, M. Lazaridou, H. Medrano, and J. Cifre. 2008. Ecophysiological strategies to overcome water deficit in herbaceous species under Mediterranean conditions. p. 247-257. In Porqueddu C., and M.M. Tavares de Sousa (eds.) Sustainable Mediterranean grasslands and their multi-functions. Options Méditerranéennes: Série A. Séminaires Méditerranéens 79. CIHEAM-IAMZ/FAO/ENMP/SPPF CIHEAM/FAO, Zaragoza, Spain.

Muhammad, A., K. Najma, G. Habib, M. Asim, and N.H. Shah. 2010. Yield comparison of forage legumes under partial stress and normal irrigation. Sarhad Journal of Agriculture 26:507-513.

Mwanamwenge, J., S.P. Loss, K.H.M. Siddique, and P.S. Cocks. 1999. Effect of water stress during floral initiation, flowering and podding on the growth and yield of faba bean (Vicia faba L.). European Journal of Agronomy 11:1-11. doi:10.1016/S11610301(99)00003-9.

Neal, J.S., W.J. Fulkerson, and R.B. Hacker. 2011. Differences in water use efficiency among annual forages used by the dairy industry under optimum and deficit irrigation. Agricultural Water Management 98:759-774. doi:10.1007/s00271-010-0229-1.

Nielsen, D.C. 1996. Potential of canola as a dryland crop in northeastern Colorado. p. 281-287. In Janick, J. (ed.) Progress in new crops. ASHS Press, Alexandria, Virginia, USA.

Pettigrew, W.T. 2004. Physiological consequences of moisture deficit stress in cotton. Crop Science 44:1265-1272. doi:10.2135/ cropsci2004.1265.

Qiu, G.Y., L. Wang, X. He, X. Zhang, S. Chen, J. Chen, et al. 2008. Water use efficiency and evapotranspiration of winter wheat and its response to irrigation regime in the north China plain. Agricultural and Forest Meteorology 148:1848-1859. doi:10.1016/j.agrformet.2008.06.010.

Radford, P.J. 1967. Growth analysis formulae - Their use and abuse. Crop Science 7:171-175. doi:10.2135/cropsci1967.0011183X000 700030001x.

Ramirez-Builes, V.H. 2007. Plant-water relationships for several common bean genotypes (Phaseolus vulgaris L.) with and without drought stress conditions. PhD thesis. University of Puerto Rico, Mayagüez, Puerto Rico.

Renna, M., A. Gasmi-Boubaker, C. Lussiana, L.M. Battaglini, K. Belfayez, and R. Fortina. 2014. Fatty acid composition of the seed oils of selected Vicia L. taxa from Tunisia. Italian Journal of Animal Science 13:308-316. doi:10.4081/ijas.2014.3193.

Rosales, M.A., E. Ocampo, R. Rodríguez-Valentín, Y. OlveraCarrillo, J. Acosta-Gallegos, and A.A. Covarrubias. 2012. Physiological analysis of common bean (Phaseolus vulgaris L.) cultivars uncovers characteristics related to terminal drought resistance. Plant Physiology and Biochemistry 56:24-34. doi:10.1016/j.plaphy.2012.04.007.
Saeed, I.A.M., and A.H. El-Nadi. 1997. Irrigation effects on the growth, yield, and water use efficiency of alfalfa. Irrigation Science 17(2):63-68. doi:10.1007/s002710050023.

Selmi, H., A. Gasmi-Boubaker, R. Mosquera Losada, H. Abdouli, B Rekik, H. Rouissi, et al. 2010. Natural vetch economic alternative to soybean meal in Tunisia. p. 63-66. In Porqueddu C., and S. Ríos (eds.) The contributions of grasslands to the conservation of Mediterranean biodiversity. Options Méditerranéennes: Série A. Séminaires Méditerranéens 92. CIHEAM/CIBIO/FAO/SEEP, Zaragoza, Spain

Stolf, R., M.E. Medri, J.A. Pimenta, M.R. Torres Boeger, J. Dias, N.G Lemos, et al. 2009. Morpho-anatomical and micromorphometrical evaluations in soybean genotypes during water stress. Brazilian Archives of Biology and Technology 52:1313-1331. doi:10.1590/ S1516-89132009000600002.

Tardieu, F., P. Cruiziat, J.L. Durand, E. Triboï, et M. Zivy. 2006. Perception de la sécheresse par la plante. Conséquences sur la productivité et sur la qualité des produits récoltés. p. 49-67. In Amigues J.P., P. Debaeke, B. Itier, G. Lemaire, B. Seguin, F. Tardieu et al. (eds.) Sécheresse et agriculture. Réduire la vulnérabilité de l'agriculture à un risque accru de manque d'eau. Expertise Scientifique Collective, Institut National De La Recherche Agronomique (INRA), France.

Villagra, P.E., and J.B. Cavagnaro. 2006. Water stress effects on the seedling growth of Prosopis argentina and Prosopis alpataco. Journal of Arid Environments 64:390-400. doi:10.1016/j. aridenv.2005.06.008

Vurayai, R., V. Emongor, and B. Moseki. 2011. Effect of water stress imposed at different growth and development stages on morphological traits and yield of Bambara Groundnuts (Vigna subterranea L. Verdc). American Journal of Plant Physiology 6:17-27. doi:10.3923/ajpp.2011.17.27.

Wu, F., W. Bao, F. Li, and N. Wu. 2008. Effects of drought stress and $\mathrm{N}$ supply on the growth, biomass partitioning and wateruse efficiency of Sophora davidii seedlings. Environmental and Experimental Botany 63:248-255. doi:10.1016/j. envexpbot.2007.11.002.

Xue, O., Z. Zhu, J.T. Musick, B.A. Stewart, and D.A. Dusek. 2006 Physiological mechanisms contributing to the increased water-use efficiency in winter wheat under deficit irrigation. Journal of Plant Physiology 163:154-164. doi:10.1016/j.jplph.2005.04.026. 